\title{
A Novel Sulfonamidoglycosylation of Glycals
}

\author{
Pedro A. Colinas* and Rodolfo D. Bravo \\ Laboratorio de Estudio de Compuestos Orgánicos (LADECOR), \\ Departamento de Química, Facultad de Ciencias Exactas, \\ Universidad Nacional de La Plata, 47 y 1151900 La Plata, Argentina \\ pcolinas@quimica.unlp.edu.ar
}

Received September 23, 2003

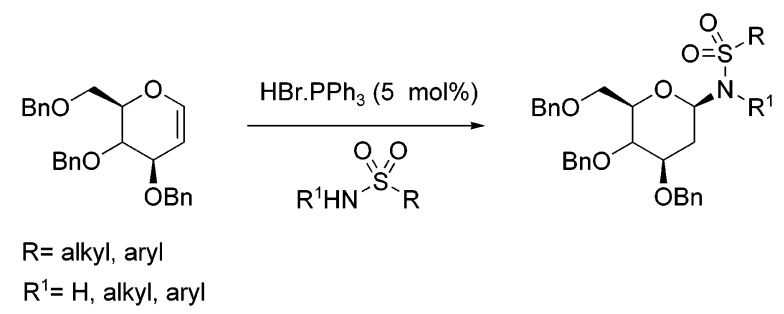

The sulfonamidoglycosylation of benzylated glycals using a catalytic amount of triphenylphosphine hydrobromide proceeded in a highly stereoselective fashion to give the $\beta$ anomers with good to high yields. This process was demonstrated with D-galactal and D-glucal. Two of the new $\mathbf{N}$-2-(deoxyglycosyl)sulfonamides were tested as inhibitors of tumor cell growth in vitro and showed antiproliferative properties in the micromolar range.

Antibacterial sulfonamides continue to play an important role in chemotherapy. Sulfonamides that inhibit the zinc enzyme, carbonic anhydrase, also have been used as diuretic, antiglaucoma, or antiepileptic drugs, and the hypoglucemic sulfonamides are extensively used in the treatment of some forms of diabetes. ${ }^{1,2}$ Recently several sulfonamides were investigated for their anticancer properties. E7010 and E7070 (Figure 1), developed by Owa's group, reached advanced stages of clinical investigation and might soon be launched as novel antitumor drugs. ${ }^{3}$ The mechanism of antitumor action of E7010 has been studied in detail; E7010 is a tubulin polymerization inhibitor, it binds to the colchicine site of the protein. ${ }^{4}$ E7070, possessing a free sulfonamido moiety probably acts as a strong carbonic anhydrase inhibitor. ${ }^{1}$

Sulfonamidoglucosides have been prepared by the reaction of glycals with iodonium di-sym-collidine perchlorate and

(1) Supuran, C. T.; Briganti, F.; Tilli, S.; Chegwidde, W. R.; Scozzafava, A. Bioorg. Med. Chem. 2001, 9, 703.

(2) Supuran, C. T.; Scozzafava, A.; Menabuoni, L.; Mincione, F.; Briganti, F.; Mincione, G. Eur. J. Pharm. Sci. 1999, 8, 317

(3) Ozawa, Y.; Sugi, N. H.; Nagasu, T.; Owa, T.; Watanabe, T.; Koyanagi, N.; Yoshino, H.; Kitoh, K.; Yoshimatsu, K. Eur. J. Cancer 2001, $37,2275$.

(4) Yoshimatsu, K.; Yamaguchi, A.; Yoshino, H.; Koyanagi, N.; Kitoh, K. Cancer Res. 1997, 57, 3208. benzenesulfonamide to afford stereoselectively $2-\beta$-iodo- 1 $\alpha$-sulfonamidohexoses. ${ }^{5}$ This class of glycosylsulfonamides were used by Danishefsky's group for the preparation of oligosaccharides with 2-aminohexose subunits. ${ }^{6}$ Later on, an<smiles>COc1ccc(S(=O)(=O)Nc2cccnc2Nc2ccc(O)cc2)cc1</smiles><smiles>NS(=O)(=O)c1ccc(S(=O)(=O)Nc2cccc3c(Cl)c[nH]c23)cc1</smiles>

Figure 1. Structures of E7010 and E7070. 
Table 1. Reaction of $p$-Toluenesulfonamide with Glycals 1a,b at Room Temperature ${ }^{a}$

\begin{tabular}{|c|c|c|c|c|c|c|}
\hline entry & glycal & sulfonamide (equiv.) & catalyst & time (min.) & $\begin{array}{l}\text { yield } \\
(\%)\end{array}$ & product \\
\hline 1 & (1a) & 2 & $\mathrm{HBr} \mathrm{PPh}_{3}$ & 90 & 87 & (3a) \\
\hline 2 & $1 \mathbf{a}$ & 1.5 & $\mathrm{HBr} \mathrm{PPh}_{3}$ & 90 & 91 & $3 a$ \\
\hline 3 & 1a & 1.1 & $\mathrm{HBr} \mathrm{PPh}_{3}$ & 90 & 90 & $\mathbf{3 a}$ \\
\hline 4 & $1 \mathbf{a}$ & 1.1 & CSA & 30 & 65 & $\mathbf{3 a}$ \\
\hline 5 & 1a & 1.1 & $\mathrm{BF}_{3} \cdot \mathrm{Et}_{2} \mathrm{O}$ & 60 & 70 & (5) \\
\hline 6 & $B n O^{\prime \prime \prime}$ & 1.1 & $\mathrm{HBr} \mathrm{PPh}_{3}$ & 90 & 80 & \\
\hline
\end{tabular}

(4a)

${ }^{a}$ All the reactions were performed in $\mathrm{CH}_{2} \mathrm{Cl}_{2}$ at room temperature using 0.05 equiv of the catalyst.

$N, N$-di(phenylsulfonyl)-2-fluoro- $\beta$-galactopyranosylamine was obtained using $N$-fluorobenzenesulfonimide. ${ }^{7}$

To the best of our knowledge, no example of sulfonamidoglycosylation of glycals with sulfonamides catalyzed by Lewis acids is known.

Various catalysts for glycosidations of glycals have been reported. Mioskowski and Falck described the preparation of 2-deoxyglucosides from glucals using triphenyl phoshine hydrobromide. ${ }^{8}$ The glucosides were obtained with good stereoselectivity (the $\alpha$-anomer predominating in all cases). Later on, Toshima et al. reported the glycosidation of glycals and different alcohols catalyzed by boron trichloride or tribromide. ${ }^{9}$ The method afforded the glycosides with excellent stereoselectivity in high yields. Under the influence of other acid catalysts such as hydrochloric and hydrofluoric acids, boron trifluoride etherate, Amberlyst $\mathrm{H}-15$ resin and $p$-toluensulfonic acid, the glycosidation is complicated by the proclivity of the cyclic enol toward allylic rearrangement, otherwise known as Ferrier rearrangement, ${ }^{10}$ resulting in 2,3unsaturated glycosides.

We first turned our attention to the conditions for the sulfonamidoglycosylation using tri- $O$-benzyl-D-galactal (1a)

(5) Griffith, D. A.; Danishefsky, S. J. J. Am. Chem. Soc. 1990, 112, 5811. (6) (a) Danishefsky, S. J.; Koseki, K.; Griffith, D. A.; Gervay, J.; Peterson, J. M.; McDonald, F. E.; Onyama, T. J. Am. Chem. Soc. 1992, 114, 8331. (b) Randolph, J. T.; Danishefsky, S. J. Angew. Chem., Int. Ed. Engl. 1994, 33, 1470. (c) Danishefsky, S. J.; Behar, V.; Randolph, J. T.; Lloyd, K. O. J. Am. Chem. Soc. 1995, 117, 5701.

(7) Albert, M.; Dax, K.; Ortner, J. Tetrahedron 1998, 54, 4839.

(8) Bolitt, V.; Mioskowski, C.; Lee, S.-G.; Falck, J. R. J. Org. Chem. 1990, 55,5812 .

(9) Toshima, K.; Nagai, H.; Ushiki, Y.; Matsumura, S. Synlett 1998, 1007.

(10) Ferrier, R. J. Top. Curr. Chem. 2001, 215, 153. or tri-O-benzyl-D-glucal (1b) and $p$-toluenesulfonamide with different catalysts in dichloromethane. The results are summarized in Table 1.

We found that the sulfonamidoglycosylation proceeded effectively at room temperature using 1.1 equiv of the sulfonamide and 0.05 equiv of $\mathrm{HBr} \cdot \mathrm{PPh}_{3} .{ }^{11}$

Higher quantities of the catalyst or the sulfonamide showed no effect on the yields or reaction times. In the case of CSA as catalyst, the reaction gave also the glycosylsulfonamide with high stereoselectivity but with lower yield (entry 4). Notably the addition reaction with boron trifluoride etherate afforded $\mathbf{5}$ in good yield (entry 5). This compound could be formed by the reaction of sulfonamide with the carbenium ion at C (3) followed by the addition of the benzyl alcohol to the double bond.

The products were easily purified by flash column chromatography and/or crystallization. In all cases the $\beta$ anomeric isomer was found (in the reaction mixtures and purified compounds). The ${ }^{1} \mathrm{H}$ and ${ }^{13} \mathrm{C}$ NMR and 2D COSY experiments and mass spectral data of the sulfonamides were in full accordance with their structure. The $\beta$-configuration was confirmed from ${ }^{1} \mathrm{H}$ NMR of the $N$-glycosylsulfonamides, where 2-Ha shows a quartet for $J_{1 \mathrm{a}, 2 \mathrm{a}}, J_{2 \mathrm{a}, 3 \mathrm{a}}, J_{2 \mathrm{a}, 2 \mathrm{e}}$ in the range

(11) General Procedure. To a solution or suspension of the glycal (1 $\mathrm{mmol})$ and the sulfonamide $(1.1 \mathrm{mmol})$ in $5 \mathrm{~mL}$ of dry methylenchloride was added, under argon, $0.05 \mathrm{mmol}$ of $\mathrm{HBr} \cdot \mathrm{PPh}_{3}$ at room temperature. After stirring for time and at the temperature indicated, the mixture was quenched with saturated $\mathrm{NaHCO}_{3}$. The organic layer was separated and washed with brine, dried over anhydrous $\mathrm{Na}_{2} \mathrm{SO}_{4}$, and concentrated in vacuo to afford a colorless oil. The residue was chromatographed on silica gel (eluent hexane/ ethyl acetate) and/or crystallized (ethyl acetate/hexane) to afford the products 3 or 4. 
of 10-12 Hz. ${ }^{12,13}$ The stereochemical outcome can be explained in terms of the strong preference of large $\mathrm{N}$ substituent for the equatorial position in the $N$-glycosides, probably reinforced by the reverse anomeric effect. ${ }^{14}$

The high $\beta$ selectivity could arise from a thermodynamically controlled reaction. Recently, Petillo et. al. reported the epimerization of some $2-\beta$-iodo- $1-\alpha$-sulfonamidohexoses catalyzed by acids. ${ }^{15}$ Although the presence of an electronwithdrawing sulfonamide is necessary to promote the isomerization, no epimerization is observed in sulfonamidoglucosides derived from benzenesulfonamide or $p$ toluenesulfonamide.

With this knowledge in hand, the selected conditions were applied to a variety of sulfonamides to show the versatility of the reaction (Scheme 1). The results are shown in Table

Scheme 1. Synthesis of $N$-Glycosylsulfonamides from 1a and 1b

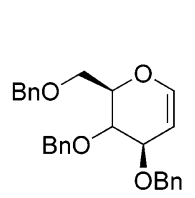

$1 a$

$1 \mathrm{~b}$

$\mathrm{R}=$ alkyl, aryl

$\mathrm{R}^{1}=\mathrm{H}$, alkyl, aryl

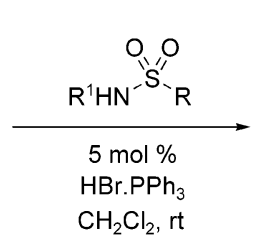

$\mathrm{CH}_{2} \mathrm{Cl}_{2}$, rt

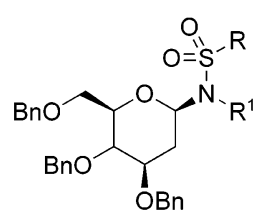

3a-h

4a-d
2. In all cases, only the $\beta$-sulfonamidoglycosides were isolated and no other products were observed.

The results shown in Table 2 indicated additional applications of the present reaction. Thus hindered sulfonamides (entries 5-7 and 10) were also smoothly coupled to 1a with high $\beta$-stereoselectivity to furnish the corresponding sulfonamides in good yields. Although sulfonamides with higher steric hindrance (entries 6, 7, and 10) needed stronger

(12) This concept was previously used by us to assign the configuration of a C-glycosylalanine: Lieberknecht, A.; Griesser, H.; Krämer, B.; Bravo, R. D.; Colinas, P. A.; Grigera, R. J. Tetrahedron 1999, 55, 6475.

(13) Also the presence of NOE effect between the H-1 and H-5 in compounds $\mathbf{3 a}$ and $\mathbf{4 a}$ confirms the configuration of the anomeric center.

(14) Kirby, A. J. The Anomeric Effect and Related Stereoelectronic Effects at Oxygen; Springer-Verlag: New York, 1983; Chapter A.

(15) Owens, J. M.; Yeung, B. K. S.; Hill, D. C.; Petillo, P. A. J. Org. Chem. 2001, 66, 1484.
Table 2. Reaction of Sulfonamides with Glycals ${ }^{a}$

\begin{tabular}{rrllccc}
\hline & & & \multicolumn{3}{c}{ time } & yield \\
entry & glycal & \multicolumn{1}{c}{ sulfonamide } & $T\left({ }^{\circ} \mathrm{C}\right)$ & $(\mathrm{h})$ & product & $(\%)$ \\
\hline 1 & $\mathbf{1 a}$ & benzyl & $\mathrm{rt}$ & 1.5 & $\mathbf{3 b}$ & 86 \\
2 & $\mathbf{1 a}$ & $p$-chlorobenzene & $\mathrm{rt}$ & 1.5 & $\mathbf{3 c}$ & 80 \\
3 & $\mathbf{1 a}$ & $p$-chlorobenzyl & $\mathrm{rt}$ & 1.5 & $\mathbf{3 d}$ & 87 \\
4 & $\mathbf{1 a}$ & ethane & $\mathrm{rt}$ & 0.5 & $\mathbf{3 e}$ & 90 \\
5 & $\mathbf{1 a}$ & $N$-methyl- $p$-toluene & $\mathrm{rt}$ & 1.5 & $\mathbf{3 f}$ & 70 \\
6 & $\mathbf{1 a}$ & $N$ - $p$-tolylbenzyl & $\mathrm{rt}$ & 4 & $\mathbf{3 g}$ & 21 \\
& & & reflux & 12 & & 67 \\
7 & $\mathbf{1 a}$ & $N$-isopropyl- $p$-toluene & $\mathrm{rt}$ & 6 & $\mathbf{3 h}$ & 16 \\
& & & reflux & 20 & & 60 \\
8 & $\mathbf{1 b}$ & benzyl & rt & 2 & $\mathbf{4 b}$ & 74 \\
9 & $\mathbf{1 b}$ & ethane & rt & 1 & $\mathbf{4 c}$ & 72 \\
10 & $\mathbf{1 b}$ & $N$ - $p$-tolylbenzyl & reflux & 15 & $\mathbf{4 d}$ & 64
\end{tabular}

${ }^{a}$ All the reactions were performed in $\mathrm{CH}_{2} \mathrm{Cl}_{2}$ using 0.05 equiv of $\mathrm{HBr} . \mathrm{PPh}_{3}$ and 1.1 equiv of sulfonamide.

conditions, the sulfonamidoglycosylation proceeded well to afford the glycosylsulfonamides.

The antitumor activity of sulfonamides $\mathbf{3} \mathbf{a}$ and $\mathbf{3 b}$ against human hepatocellular carcinoma cell lines Hep-G2 was assessed. ${ }^{16}$ They act as potent inhibitors of growth (in the 14-20 $\mu \mathrm{M}$ range), which make them interesting leads for the development of novel anticancer agents.

The sulfonamides $\mathbf{3 e}$ and $\mathbf{4 c}$, bearing an alkyl moiety, could be useful as cyclooxygenase inhibitors. ${ }^{17}$

In conclusion, we have developed a novel method for the stereoselective production of $\beta$-sulfonamidoglycosides. The preparation is not only high yielding but also very amenable to multigram scale-up. Some of these new glycosylsulfonamides have been shown to be inhibitors of hepatocelullar carcinoma cell lines. Further studies with other tumor cell lines will be reported in due course.

Acknowledgment. We thank CIC (Pcia. De Buenos Aires) for financial support, Dr. J. L. Jios and Dr. Carlos Della Védova for NMR measurements, and Dr. Alicia S. Cánepa and Dr. Albrecht Lieberknecht for valuable discussions.

Supporting Information Available: Spectroscopic data for compounds 3a,b,e,f and 4a. This material is available free of charge via the Internet at http://pubs.acs.org.

OL035838G

(16) Bravo, M. G. de. INIBIOLP (UNLP-CONICET), Fac. Cs. Médicas (personal communication).

(17) Dannhardt, G.; Kiefer, W. Eur. J. Med. Chem. 2001, 36, 109. 